Article

\title{
Formulation of Laccase Nanobiocatalysts Based on Ionic and Covalent Interactions for the Enhanced Oxidation of Phenolic Compounds
}

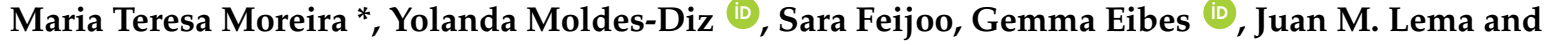 \\ Gumersindo Feijoo \\ Department of Chemical Engineering, Institute of Technology, University of Santiago de Compostela, \\ 15782 Santiago de Compostela, Spain; yolanda.moldes@usc.es (Y.M.-D.); s.feijoomoreira@student.tudelft.nl (S.F.); \\ gemma.eibes@usc.es (G.E.); juan.lema@usc.es (J.M.L.); gumersindo.feijoo@usc.es (G.F.) \\ * Correspondence: maite.moreira@usc.es; Tel.: +34-881-816-792
}

Received: 20 July 2017; Accepted: 16 August 2017; Published: 18 August 2017

Featured Application: Development and potential use of nanobiocatalysts for the removal of phenolic compounds as well as other related xenobiotics present in industrial wastewaters.

\begin{abstract}
Oxidative biocatalysis by laccase arises as a promising alternative in the development of advanced oxidation processes for the removal of xenobiotics. The aim of this work is to develop various types of nanobiocatalysts based on laccase immobilized on different superparamagnetic and non-magnetic nanoparticles to improve the stability of the biocatalysts. Several techniques of enzyme immobilization were evaluated based on ionic exchange and covalent bonding. The highest yields of laccase immobilization were achieved for the covalent laccase nanoconjugates of silica-coated magnetic nanoparticles ( $\left.2.66 \mathrm{U} \mathrm{mg}^{-1} \mathrm{NPs}\right)$, formed by the covalent attachment of the enzyme between the aldehyde groups of the glutaraldehyde-functionalized nanoparticle and the amino groups of the enzyme. Moreover, its application in the biotransformation of phenol as a model recalcitrant compound was tested at different $\mathrm{pH}$ and successfully achieved at $\mathrm{pH} 6$ for $24 \mathrm{~h}$. A sequential batch operation was carried out, with complete recovery of the nanobiocatalyst and minimal deactivation of the enzyme after four cycles of phenol oxidation. The major drawback associated with the use of the nanoparticles relies on the energy consumption required for their production and the use of chemicals, that account for a major contribution in the normalized index of $5.28 \times 10^{-3}$. The reduction of cyclohexane (used in the synthesis of silica-coated magnetic nanoparticles) led to a significant lower index $\left(3.62 \times 10^{-3}\right)$; however, the immobilization was negatively affected, which discouraged this alternative.
\end{abstract}

Keywords: laccase; nanocatalyst; immobilization; phenol; sequential batch reactor

\section{Introduction}

Laccase is a high potential oxidative enzyme with broad substrate specificity towards aromatic compounds, which makes it a promising candidate for the degradation of xenobiotics containing hydroxyl and amine groups [1-3]. However, the relatively low stability of the free enzyme arises as a major technical hurdle that hampers its large-scale application [4]. Beyond the potentiality of protein engineering and directed evolution to change enzyme conformation [5], enzyme immobilization can be applied to enhance the protein stability by the prevention of autolysis or proteolysis, rigidification of the enzyme structure via multipoint covalent attachment, and generation of favorable microenvironments [6-8]. This method has been demonstrated to improve the activity and stability of the biocatalyst in both aqueous and organic phases, provided that the support permits the diffusion of 
the substrate to the active site of the enzyme [9]. Furthermore, it may facilitate the simple recovery of the enzymes by centrifugation, sedimentation, or other physical separation methods and reuse in continuous systems. However, immobilized enzymes can also encounter several drawbacks, such as mass transfer limitations or interaction between the enzyme and the support that may reduce its catalytic potential [10].

Conceptually, there are two basic methods for enzyme immobilization, as the enzyme-support link can take place by physical or chemical interactions. Physical coupling methods include the entrapment of the enzyme within a tridimensional matrix, its encapsulation in an organic or inorganic polymer, and its adsorption to the support surface by ionic exchange [11], whereas covalent bonding assures the irreversible binding of the enzyme to the support matrix.

Among a wide range of alternatives, the large specific surface area characteristic of nanomaterials makes this type of support an ideal candidate for enzyme immobilization [12]. The efficiency of ionic exchange depends on the $\mathrm{pH}$ and ionic strength of the medium as well as the hydrophobic nature of the nanoparticle surface [13-15]. Regarding covalent bonding, nanoparticles may provide a homogeneous core-shell structure, which can be functionalized to react with nucleophilic groups on the enzyme [16]. Most enzymes are covalently attached to the lysine amino groups, which are typically present on the protein surface [17]. Several factors, including $\mathrm{pH}$, ionic strength, protein concentration, additives, and nanoparticles structure (porous or non-porous material) may affect the biocatalyst and the effectiveness of covalent bonding between the enzyme and the support [16,18].

The immobilization of laccase on different types of nanoparticles such as silver and gold nanoparticles [19], chitosan-coated magnetic nanoparticles [20], and carbon nanotubes [21] has been demonstrated in recent years, although few processes have been used for practical applications at full-scale [22]. The main aim of this work is to perform the efficient immobilization of laccase on different types of magnetic and non-magnetic nanoparticles. Two different immobilization procedures will be followed: ionic exchange between the enzyme and the nanoparticle, and covalent bonding of the enzyme protein to the surface of the nanoparticle using glutaraldehyde or carbodiimide as cross-linkers [23,24]. Glutaraldehyde, a bifunctional and versatile agent, may react with different enzyme moieties, principally involving primary amino groups of proteins, although it may eventually react with other groups such as thiols, phenols, and imidazoles [25]. On the other hand, carbodiimide is used to form amide linkage between carboxylates and amino terminal groups from the enzyme [26]. The catalytic activity of the different nanobiocatalysts will be evaluated in terms of the biotransformation potential of phenol as the model compound. Once the successful immobilization of laccase is proved, we will aim to examine how the application of life cycle principles may be helpful in the reformulation of the production scheme of the most suitable support.

\section{Materials and Methods}

\subsection{Chemicals and Nanoparticles for Enzyme Immobilization}

(3-Aminopropyl)triethoxysilane (APTES) ( $\geq 98 \%), \quad 2,2^{\prime}$-azinobis(3-ethylbenzothiazoline-6sulphonic acid) (ABTS) ( $\geq 98 \%)$, glutaraldehyde (25\%), 3-(Ethyliminomethyleneamino)- $N, N$ dimethylpropan-1- amine (EDC) $(\geq 98 \%)$, and fumed silica nanoparticles were purchased from Sigma-Aldrich (St. Louis, MO, USA). Non-coated magnetite nanoparticles, single-core silica-coated magnetic nanoparticles (FeO-2206W), multi-core silica-coated magnetic nanoparticles (S-57), polyacrylic acid nanoparticles (FeO-2204W and FeO-36), and polyethyleneimine-coated magnetic nanoparticles (VOZ-19) were supplied by Nanogap (Ames, Spain). Detailed characteristics of the nanoparticles evaluated are presented in Table 1. 
Table 1. Characteristics of the different nanoparticles.

\begin{tabular}{|c|c|c|}
\hline Type of Nanoparticles & Size (nm) & Concentration (mg NPs $\mathrm{mL}^{-1}$ ) \\
\hline Fumed silica nanoparticles (fsNP) & 7 & 59 \\
\hline \multicolumn{3}{|l|}{ Silica-coated magnetic nanoparticles } \\
\hline FeO-2206W (single-core) & $21.5 \pm 2.1$ & 5 \\
\hline S-57 (multi-core) & $11.8 \pm 2.4$ & 10.9 \\
\hline \multicolumn{3}{|c|}{ Polyacrylic acid (PAA) magnetic nanoparticles } \\
\hline $\mathrm{FeO}-2204 \mathrm{~W}$ & $10.1 \pm 2.4$ & 20.5 \\
\hline $\mathrm{FeO}-36$ & $23.1 \pm 4.9$ & 16.2 \\
\hline \multicolumn{3}{|c|}{ Polyethylenimine (PEI) magnetic nanoparticles } \\
\hline VOZ-19 & $10 \pm 1.2$ & 56 \\
\hline $\begin{array}{l}\text { Non-coated magnetite } \\
\text { nanoparticles }\end{array}$ & $9.9 \pm 1.4$ & 17.4 \\
\hline
\end{tabular}

\subsection{Laccase Activity}

Laccase activity from Trametes versicolor (activity $10 \mathrm{U} \mathrm{mg}^{-1}$, Sigma-Aldrich, St. Louis, MO, USA) was measured according to Zimmerman et al. [23]. Following this protocol, $50 \mu \mathrm{L}$ of sample was added to $150 \mu \mathrm{L}$ of $0.267 \mathrm{mM}$ ABTS (in Mcllvaine buffer; $\mathrm{pH}$ ) in 96-well plates. The ABTS oxidation was monitored by measuring the absorbance at $420 \mathrm{~nm}$ for $7 \mathrm{~min}$ (with intervals of $6 \mathrm{~s}$ ), with a molar extinction coefficient of the cation radical of $36,800 \mathrm{M}^{-1} \mathrm{~cm}^{-1}$ [24]. One unit $\mathrm{U}$ of activity was defined as the amount of enzyme capable of producing $1 \mu \mathrm{mol}$ of the cation radical per min.

\subsection{Functionalization of Laccase onto Silica and Silica-Coated Magnetic Nanoparticles}

The immobilization process for fumed silica nanoparticles (fsNP) and silica-coated magnetic nanoparticles (smNP) requires their previous functionalization, in which reactive groups are added based on the modification of their surface by the addition of (3-aminopropyl)triethoxysilane (APTES) [23]. The protocol starts with the incubation of the nanoparticles in phosphate buffer $(100 \mathrm{mM}$, $\mathrm{pH} 7$ ) and APTES (0.8 mmol APTES $\mathrm{g}^{-1}$ nanoparticles) under agitation (100 rpm) for $12 \mathrm{~h}$ at room temperature. The residual APTES concentration in the supernatants was monitored as follows: $50 \mu \mathrm{L}$ of $5.3 \mathrm{mM}$ glutaraldehyde solution was added to $150 \mu \mathrm{L}$ supernatant. The yellow coloration due to the imine bond resulting from the chemical reaction of APTES with glutaraldehyde was measured spectrophotometrically at $390 \mathrm{~nm}$. After four washing steps, no residual APTES was detected.

\subsection{Immobilization of Laccase onto Silica and Polyethylenimine Nanoparticles}

The amino-functionalized nanoparticles were then used to perform the immobilization of laccase according to the sorption-assisted immobilization (SAI) protocol [23], where the amino-functionalized nanoparticles and laccase $\left(15 \mathrm{mg} \mathrm{mL}^{-1}\right)$ were incubated in phosphate buffer $(\mathrm{pH} 7,100 \mathrm{mM})$ at $4{ }^{\circ} \mathrm{C}$ and $100 \mathrm{rpm}$ for $2 \mathrm{~h}$. Next, glutaraldehyde was added dropwise to the mixture of nanoparticles and laccase, and the solution was incubated for an additional $18 \mathrm{~h}$. The unreacted glutaraldehyde and the excess and unstable bound enzymes were washed away.

The immobilization procedure for the polyethylenimine-coated magnetic nanoparticles (PEI-mNPs) was identical to the one previously described for silica nanoparticles except for the step of functionalization with APTES (not required here). The enzymatic activity of both NP-laccase conjugates and supernatants was measured in these immobilization processes as well as in the following ones to determine the activity yield, washing loss, and enzyme load. Variable concentrations of glutaraldehyde and laccase activity were used in the immobilization process: $4-8 \mathrm{mmol} \mathrm{g}^{-1} \mathrm{NPs}$ and $0.9-1.88 \mathrm{U} \mathrm{mg}^{-1}$ NPs, respectively. 


\subsection{Immobilization of Laccase onto Polyacrylic Acid-Coated Magnetic Nanoparticles}

The functionalization of the nanoparticles was conducted according to the method described by Nobs et al. [24]. The nanoparticles $\left(5 \mathrm{mg} \mathrm{mL}^{-1}\right)$ were suspended in 2-( $N$-morpholino)ethanesulfonic acid (MES) buffer $0.1 \mathrm{M}$ (pH 4.7), and EDC (12 $\left.\mathrm{mg} \mathrm{mL}^{-1}\right)$ and N-hydroxysuccinimide (NHS, $\left.33 \mathrm{mg} \mathrm{mL}^{-1}\right)$ were added with gentle agitation $(100 \mathrm{rpm})$ at room temperature $\left(25^{\circ} \mathrm{C}\right)$ to complete the reaction after $24 \mathrm{~h}$. The unreacted NHS and EDC were removed by repeated washing and centrifugation (4000 rpm, $6 \mathrm{~min}$ ), and were resuspended in MES buffer (0.1 M, pH 4.7). The amino-functionalized nanoparticles were then used to perform the immobilization of laccase by the aforementioned SAI method [23] with 8 mmol glutaraldehyde $\mathrm{g}^{-1} \mathrm{NPs}$ and $1.88 \mathrm{U}$ laccase $\mathrm{mg}^{-1} \mathrm{NPs}$.

\subsection{Immobilization of Laccase by Ionic Exchange on Magnetite Nanoparticles}

Laccase immobilization in magnetite nanoparticles (lacking any external coating) was carried out by ionic exchange of the enzyme with magnetite nanoparticles. Laccase was added $\left(0.55 \mathrm{U} \mathrm{mg}^{-1} \mathrm{NPs}\right)$ to previously washed nanoparticles and incubated at $4{ }^{\circ} \mathrm{C}, 100 \mathrm{rpm}$, and pH 5 for $4 \mathrm{~h}$. After incubation, the nanobiocatalyst was washed five times in sodium phosphate buffer before storage.

2.7. Biotransformation of Phenol by Laccase Immobilized onto fsNPs and Single-Core Silica-Coated Magnetic Nanoparticles in Batch Operation

The oxidation of phenol by the enzymatic system was investigated in a reaction medium containing phenol $\left(10 \mathrm{mg} \mathrm{L}^{-1}\right)$ dissolved in phosphate buffer $(100 \mathrm{mM}, \mathrm{pH}$ 7) and immobilized laccase $\left(1000 \mathrm{U} \mathrm{L}^{-1}\right)$ onto fsNPs or smNPs (FeO-2206W) in 10-mL flasks. In parallel, experiments with free laccase as well as controls lacking laccase with functionalized fsNPs and mNPs were also carried out. Samples were withdrawn at specific time intervals for $24 \mathrm{~h}$ to monitor phenol removal.

\subsection{Consecutive Cycles of Batch Biotransformation of Phenol by Laccase Immobilized onto Single-Core Silica-Coated Magnetic Nanoparticles}

Variable $\mathrm{pH}$ values (5-7) were investigated to perform the biotransformation of phenol $\left(10 \mathrm{mg} \mathrm{L}^{-1}\right)$ by laccase immobilized on silica-coated magnetic nanoparticles $\left(1000 \mathrm{U} \mathrm{L}^{-1}\right)$. Acetate buffer $(100 \mathrm{mM})$ was applied for $\mathrm{pH} 5$, while in the case of $\mathrm{pH} 6$ and 7, phosphate buffer $(100 \mathrm{mM})$ was used. Thereafter, the operation of the enzymatic system was conducted in a tank reactor $(100 \mathrm{~mL})$ under stirring at room temperature for several consecutive cycles. The reaction medium consisted of phenol $\left(10 \mathrm{mg} \mathrm{L}^{-1}\right)$, phosphate buffer $(100 \mathrm{mM}, \mathrm{pH} 6)$, and a single initial pulse of laccase $\left(1000 \mathrm{U} \mathrm{L}^{-1}\right)$ immobilized onto FeO-2206W smNP. The effluent of the reactor was withdrawn at the end of the cycle and the nanobiocatalyst was recovered by an external magnetic field before a new cycle started.

\subsection{Phenol Analysis}

Phenol concentration was determined by high-performance liquid chromatography (HPLC) at a detection wavelength of $270 \mathrm{~nm}$ on a Jasco XLC HPLC (Jasco Analítica, Madrid, Spain). This equipment was coupled with a diode detector $3110 \mathrm{MD}$, a $4.6 \times 150 \mathrm{~nm}$ Gemini reversed-phase column $(3 \mu \mathrm{m}$ C18 $110 \AA$ A) from Phenomenex (supplied by Jasco Analítica, Madrid, Spain), and an HP ChromNav data processor. A $25-\mu \mathrm{L}$ sample volume was injected into the column. The mobile phase contained $50 \%$ acetonitrile and $50 \%$ water. The flow rate was fixed at $0.4 \mathrm{~mL} \mathrm{~min}{ }^{-1}$ under isocratic conditions.

\subsection{Life Cycle Assessment Methodology}

Life Cycle Assessment (LCA) is a methodology that aims to analyze products, processes, and/or services from an environmental point of view, and should be part of the decision-making process toward sustainability [27]. The guidelines established by International Organization for Standardization (ISO) standards [28] have been considered to perform the LCA study. The environmental profiles of the silica-coated mNPs production were determined according to 
the production route described in a previous paper [29]. In a typical synthesis of silica-coated mNPs, polyoxyethylene(5)nonylphenyl ether (Igepal CO-520) and cyclohexane are mechanically stirred before the addition of oleic-acid magnetite nanoparticles ( $2.5 \% \mathrm{wt}$ in cyclohexane). Finally, ammonium hydroxide solution and tetraethyl orthosilicate (TEOS) are added consecutively to form a transparent red solution of reverse micro-emulsion. The core-shell nanoparticles are precipitated with isopropanol (IPA) to disrupt the reverse microemulsion and are then washed extensively with IPA and deionized water. Finally, the core-shell nanoparticles are re-dispersed in deionized water. In the case of the production of magnetic nanoparticles with a thin silica-coating, the procedure is similar except for the concentration of cyclohexane ( $0.5 \%$, five times lower). Inventory data for the foreground systems were obtained from a semi-pilot unit and data from the background system (production of electricity, chemicals, and wastewater treatment) were taken from Ecoinvent database ${ }^{\circledR}$ version 3 [30-32] and, when possible, updated for Spain [33]. The environmental assessment was conducted using characterization factors from ReCiPe Midpoint methodology [34] and the following impact categories were considered in the analysis: climate change, ozone depletion, terrestrial acidification, freshwater eutrophication, marine eutrophication, human toxicity, photochemical oxidant formation, terrestrial ecotoxicity, freshwater ecotoxicity, marine ecotoxicity, and fossil depletion. SimaPro version 7.3.3 (PRé Consultants, Amersfoort, The Netherlands) was the software used for the computational implementation of the life cycle inventory data and the computation of the environmental profiles [35].

\section{Results and Discussion}

\subsection{Immobilization of Laccase onto Different Types of Nanoparticles}

Several strategies of laccase immobilization were evaluated on magnetic and non-magnetic nanoparticles to obtain various types of nanobiocatalysts. The enzymatic activities of both NP-laccase conjugates and supernatants were measured to determine the activity yield, washing loss, and enzyme load (Table 2). The tradeoff analysis of the different outcomes will be critical to identify the most suitable option for its further use.

Table 2. Activity yield, washing loss, and enzyme loading for the optimal doses in the immobilization processes.

\begin{tabular}{|c|c|c|c|}
\hline Different Types of Nanoparticles & $\begin{array}{l}\text { Washing Loss } \\
(\%)\end{array}$ & $\begin{array}{c}\text { Activity Yield } \\
(\%)\end{array}$ & Enzyme Loading ( $\mathrm{U} \mathrm{mg}^{-1} \mathrm{NPs}$ ) \\
\hline \multicolumn{4}{|l|}{ Covalent immobilization } \\
\hline Fumed silica nanoparticles (fsNP) & $5.6 \pm 1.3$ & $100 \pm 6.1$ & $1.78 \pm 0.07$ \\
\hline \multicolumn{4}{|l|}{ Silica-coated magnetic nanoparticles } \\
\hline FeO-2206W (single-core) & $16.4 \pm 2.81$ & $99.7 \pm 0.35$ & $2.66 \pm 0.65$ \\
\hline S-57 (multi-core) & $66.63 \pm 1.67$ & $31.3 \pm 0.76$ & $0.42 \pm 0.05$ \\
\hline \multicolumn{4}{|c|}{ Polyacrylic acid (PAA) magnetic nanoparticles } \\
\hline $\mathrm{FeO}-2204 \mathrm{~W}$ & $96.83 \pm 1.4$ & $2.55 \pm 6.5$ & $0.11 \pm 0.34$ \\
\hline FeO-36 & $99.7 \pm 2.34$ & $0.12 \pm 2.3$ & $0.01 \pm 0.24$ \\
\hline \multicolumn{4}{|c|}{ Polyethylenimine (PEI) magnetic nanoparticles } \\
\hline VOZ-19 & $27.18 \pm 0.08$ & $80.5 \pm 0.21$ & $1.54 \pm 0.03$ \\
\hline \multicolumn{4}{|l|}{ Ionic exchange immobilization } \\
\hline $\begin{array}{l}\text { Non-coated magnetite } \\
\text { nanoparticles }\end{array}$ & $45.3 \pm 0.9$ & $58.5 \pm 1.5$ & $0.69 \pm 0.05$ \\
\hline
\end{tabular}

Covalent bonding produces stronger bonds between the enzyme and the support, allowing its reuse more easily than with other available immobilization methods $[36,37]$ and preventing the leaching of enzymes from the support [38,39]. In this study, different coatings as well as single- and multi-core nanoparticles were evaluated for laccase immobilization (Table 2). The covalent bonding between the supports with carboxylic groups (polyacrylic acid) did not result in satisfactory immobilization (yields lower than $5 \%$ ). This may be due to excessive crosslinking of the protein molecule (due to the presence 
of both $\mathrm{NH}_{2}$ and $\mathrm{COOH}$ groups in the enzyme and also to the instability of carbodiimide, which led to very low activity yields, as was also observed in other studies with activity yields below $14 \%)[40,41]$.

However, laccase was successfully immobilized in other nanoparticles such as PEI-mNPs, which showed an activity yield higher than $80 \%$ (Table 2). The stability of this biocatalyst was inferior to laccase immobilized onto fsNPs and FeO-2206-W smNPs (Table 2). In the specific case of PEI-mNPs, the enzyme activity after three months was $50 \%$, which was significantly lower than those of fsNPs and $\mathrm{FeO}-2206-\mathrm{W}$ (93\% and 99\%, respectively). Similar results were observed for a previous report with silica nanoparticles, using remarkably higher dosages of APTES and glutaraldehyde than the values considered in this research [23]. The rationale behind the high activity yields is attributed to the fact that immobilized laccases on this type of support would have high affinity for standard substrates such as ABTS. For instance, Arca-Ramos et al. [42] reported the hyperactivation of laccase from T. versicolor after the formation of covalent bonds with silica nanoparticles; whereas Matijosyte et al. [11] described a similar behavior for laccase from T. villosa (activity recovery up to 148\%) after the formation of cross-linking aggregates $\left(\right.$ CLEAS $^{\circledR}$, CLEATechnologies, Delft, The Netherlands).

The process of immobilization by ionic exchange is based on the interaction of the charged groups of the enzyme with the groups of opposite charges in the support. It provides a weak bond between the enzyme and the support so that the native structure of the enzyme is unaltered. Moreover, the bonding is reversible and it is sensitive to changes in the $\mathrm{pH}$ and ionic strength, which can lead to the recovery of the support [9]. When this approach was considered for the immobilization of laccase, not only limited yield was evidenced, but also the change of basic $\mathrm{pH}$ led to enzyme desorption. When performing the immobilization of laccase at different $\mathrm{pH}$ values, the best results were observed when the immobilization process was performed at $\mathrm{pH} 5$ with an activity yield higher than $50 \%$ (Table 2), possibly because the point of zero charge (PZC) of the magnetite is between $\mathrm{pH}$ 6.5-7.9 [43], while the isoelectric point of laccase is at $\mathrm{pH} 3$ [44]. The main drawback is that laccase stability decreases with lower $\mathrm{pH}$, which was evidenced by the reduction of the immobilized enzyme. Considering the best results of activity yield and enzyme load, fsNPs and FeO-2206W smNPs were selected for the following experiments of phenol biotransformation.

\subsection{Biotransformation of Phenol by Laccase Immobilized onto fsNPs and Silica-Coated Magnetic Nanoparticles in Batch Operation}

The capacity of free and immobilized enzymes onto fsNPs and FeO-2206W smNPs to transform phenol was assessed in batch operation. The results showed that the higher phenol transformation was achieved by free laccase ( $>75 \%$ ), whereas phenol conversion was around $23 \%$ and $48 \%$ for fsNPs and $\mathrm{FeO}-2206 \mathrm{~W}$ smNPs, respectively (Figure 1). Lower activity of immobilized laccase towards phenolic substrates has also been previously reported. For instance, Arca-Ramos et al. [42] found that bisphenol A degradation rate was much slower for immobilized laccases (from 6- to 26-fold lower than that of the free enzyme). This lower reaction rate was related to the potential aggregation of the nanoparticles which could reduce substrate accessibility. Wang et al. [45] studied phenol degradation by immobilized laccase on magnetic silica nanoparticles, and similar results were observed at $\mathrm{pH} 7$. The rate of phenol conversion for laccase immobilized onto FeO-2206W smNPs $\left(2.01 \mu \mathrm{M} \mathrm{h}^{-1}\right)$ is almost two times higher than that for fsNPs. Controls with phenol lacking laccase but with functionalized nanoparticles were performed, with no decrease in phenol concentration in all cases after $24 \mathrm{~h}$.

Kurniawati and Nicell [46] reported that laccase can be inactivated due to the presence of free radicals in the reaction medium generated from phenol transformation (not by the substrate). However, this effect was only evident at phenol concentrations of $2000 \mu \mathrm{M}(188 \mathrm{mg} / \mathrm{L})$, almost 20-fold higher than that used in the present work. Hence, no enzymatic activity changes occurred in any of the experiments with a noticeable enzyme deactivation when performing the experiment with free laccase. 


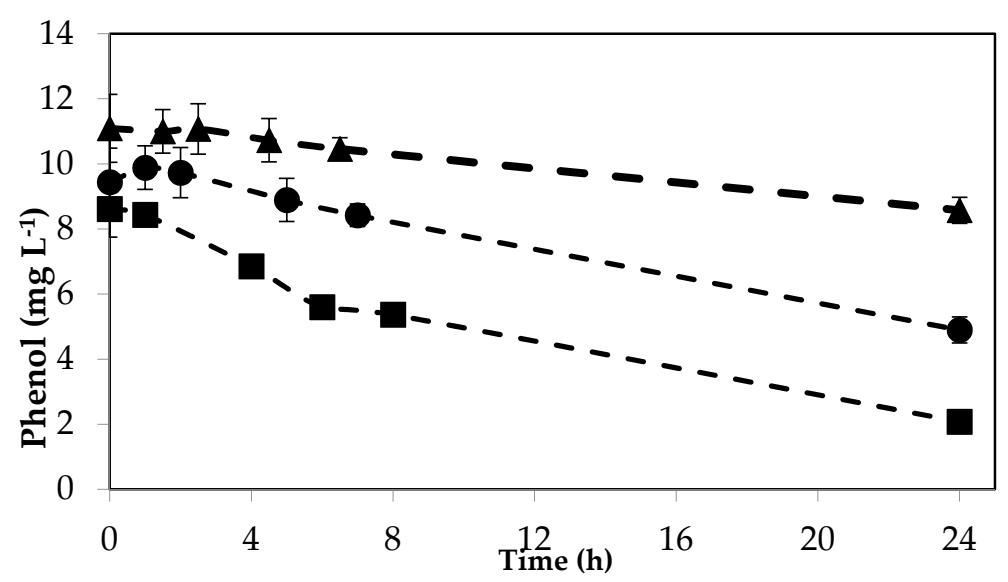

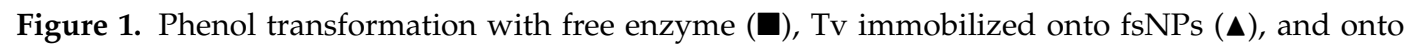
FeO-2206W (•) over $24 \mathrm{~h}$ at $\mathrm{pH} 7$.

According to the results, the nanobiocatalyst with FeO-2206W as a support seems to be the most adequate, as it achieved higher phenol biotransformation yields. Moreover, the separation of the nanobiocatalyst should be much simpler under a magnetic field, while intense centrifugation should be required when considering fumed silica nanoparticles. Accordingly, the single-core silica-coated nanobiocatalyst was used to prove its potential of reuse for phenol biotransformation in sequential batches.

\subsection{Sequential Batch Biotransformation of Phenol by Laccase Immobilized onto Silica-Coated Magnetic Nanoparticles}

Due to the remarkable effect of $\mathrm{pH}$ on phenol conversion reported in previous works [45,47], the biotransformation of phenol was assessed at different $\mathrm{pH}$ levels $(5,6$, and 7). The conversion efficiencies and rates are shown in Table 3. An improvement of phenol conversion was observed when the $\mathrm{pH}$ was decreased to 6 or 5 , which lead to an increase of $16 \%$. A similar $\mathrm{pH}$ range was found suitable for phenol by immobilized enzyme onto silica-coated magnetic nanoparticles [45]. Furthermore, the enzymatic activity was maintained constant in all the experiments. The immobilized laccase retained $95 \%, 97 \%$, and $100 \%$ of its initial activity at $\mathrm{pH} 5,6$, and 7 , respectively, after incubation at room temperature for $24 \mathrm{~h}$.

Table 3. Phenol biotransformation at variable $\mathrm{pH}$ levels by laccase immobilized onto silica-coated magnetic nanoparticles (FeO-2206W) for $24 \mathrm{~h}$.

\begin{tabular}{ccc}
\hline $\mathbf{p H}$ & Phenol Biotransformation (\%) & Biotransformation Rate $\left(\mathbf{m g ~ L}^{-\mathbf{1}} \mathbf{h}^{\mathbf{- 1}}\right)$ \\
\hline 5 & 67.9 & 0.383 \\
6 & 63.9 & 0.326 \\
7 & 48.1 & 0.189 \\
\hline
\end{tabular}

The reusability of the nanobiocatalyst was assessed in consecutive cycles of $24 \mathrm{~h}$. It was observed that phenol transformation was higher than $60 \%$ and was maintained constant after four cycles (Figure 2). In other reports, phenol was almost entirely biotransformed in consecutive cycles with laccase immobilized on magnetic mesoporous silica nanoparticles with a dose of enzyme 18 times higher [45]. The immobilized laccase retained $97 \%$ of its initial activity after the consecutive batch treatments of phenol with magnetic separation. 


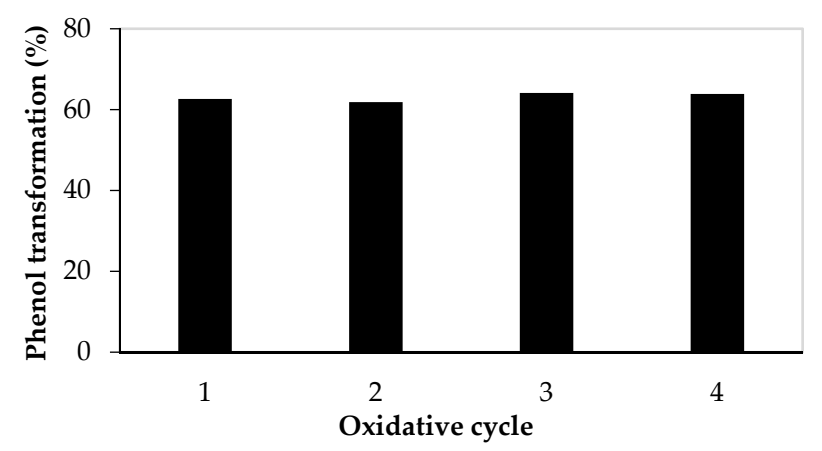

Figure 2. Phenol transformation in subsequent cycles of enzymatic treatment with laccase immobilized onto FeO-2206W (pH 6).

\subsection{Environmental Indicators of the Single-Core Magnetic Nanoparticle}

The development of new processes must comply with sustainability criteria. The methodology applied for the holistic assessment of the most suitable support was based on a life cycle perspective [48], which would include all aspects of activities during the life of a product, such as the extraction of raw materials and resources, production processes, use of products, recovery, recycling of some fractions, and the final disposal at the end-of-life stage.

In this study, inventory data for the foreground systems (direct inputs and outputs for each scenario) such as electricity requirements (estimated with power and operational data from the different units: reactors, dryers, heaters) as well as the use of chemicals and water were average data from semi-pilot scale experiments, obtained by on-site measurements of production processes developed for a time period of three months. The environmental assessment was conducted using characterization factors from ReCiPe Midpoint methodology [34], and the impact categories for the different mNP production routes are displayed considering one gram of FeO-2206W mNPs as a functional unit (Table 4).

Table 4. Normalized environmental impacts associated with the production of silica-coated mNPs (FeO-2206W) and silica thin shell per $\mathrm{g}$ of $\mathrm{mNP}$.

\begin{tabular}{ccc}
\hline \multicolumn{3}{c}{ Scenarios } \\
\hline Impact Category & Silica-Coated mNPs & Silica Thin Shell \\
\hline Climate change & $1.43 \times 10^{-4}$ & $1.03 \times 10^{-4}$ \\
Ozone depletion & $3.69 \times 10^{-6}$ & $2.42 \times 10^{-6}$ \\
Terrestrial acidification & $1.83 \times 10^{-4}$ & $1.30 \times 10^{-4}$ \\
Freshwater eutrophication & $9.11 \times 10^{-4}$ & $5.42 \times 10^{-4}$ \\
Marine eutrophication & $2.12 \times 10^{-5}$ & $1.45 \times 10^{-5}$ \\
Human toxicity & $5.93 \times 10^{-4}$ & $3.98 \times 10^{-4}$ \\
Photochemical oxidant formation & $1.33 \times 10^{-4}$ & $9.05 \times 10^{-5}$ \\
Terrestrial ecotoxicity & $6.18 \times 10^{-6}$ & $4.37 \times 10^{-6}$ \\
Freshwater ecotoxicity & $1.22 \times 10^{-3}$ & $8.36 \times 10^{-4}$ \\
Marine ecotoxicity & $1.45 \times 10^{-3}$ & $9.84 \times 10^{-4}$ \\
Fossil depletion & $6.20 \times 10^{-4}$ & $5.18 \times 10^{-4}$ \\
Normalized index & $5.28 \times 10^{-3}$ & $3.62 \times 10^{-3}$ \\
\hline
\end{tabular}

The normalization results show that the impacts associated with the consumption of energy are dominant, but chemicals used in the formulations and for re-dispersion are also relevant. Regarding electricity, it is consumed for stirring, and the mechanical agitation required to obtain the transparent red solution of reverse micro-emulsion until complete reaction is remarkable $(97 \%$ of the total electrical requirements). Regarding chemicals, the cyclohexane required in the formulation is the environmental critical chemical, since it is responsible for more than $85 \%$ of burdens derived from chemicals contributions regardless the impact category. Aiming to reduce the impacts, we also considered 
the use of a lower dose of cyclohexane to obtain a thin silica coating on the nanoparticle. Although the environmental impact was reduced, the immobilization of the enzyme was negatively affected by $40 \%$, which was detrimental to the overall efficiency of the process. However, it should be highlighted that the production systems have been assessed at the pilot scale and optimizations should be required for large-scale application.

\section{Conclusions}

The study compared the immobilization of a commercially available T. versicolor laccase onto glutaraldehyde-activated, sulfo-NHS/EDC-activated magnetic and non-magnetic nanoparticles by covalent binding and onto magnetic nanoparticles by ion exchange, as well as its use as a nanobiocatalyst for phenol biotransformation. In summary, the most efficient biotransformation and the best activity yield was obtained by using laccase immobilized onto silica-coated magnetic nanoparticles. The magnetic nanobiocatalyst achieved a phenol biotransformation higher than $60 \%$. One major outcome of this study is that the immobilized laccase is magnetically recoverable and can actually be reused in repeated cycles of phenol removal. The easy recovery of the nanobiocatalyst from the reaction media is a remarkable advantage from an operational perspective. Regarding the environmental impacts associated with the production of silica-coated magnetic nanoparticles, the use of energy and chemicals used in the formulations and for re-dispersion are the major contributors. Aiming to reduce the impacts, the use of a lower dose of cyclohexane implied lower environmental impact but negatively affected the immobilization yield of the enzyme, which discouraged this modification in the production process.

Acknowledgments: This work was financially supported by the Spanish Ministry of Economy and Competitiveness (CTQ2013-44762-R and CTQ2016-79461-R, program co-funded by FEDER). The authors belong to the Galician Competitive Research Group GRC 2013-032, program co-funded by FEDER. Yolanda Moldes-Diz thanks the Spanish Ministry of Economy and Competitiveness for her predoctoral fellowship.

Author Contributions: Maria Teresa Moreira, Juan M. Lema and Gumersindo Feijoo conceived and designed the experiments; Yolanda Moldes-Diz performed the experiments; Sara Feijoo performed the LCA study, Maria Teresa Moreira and Gemma Eibes analyzed the data and revised the different versions of the manuscript; Maria Teresa Moreira. and Yolanda Moldes-Diz wrote the paper.

Conflicts of Interest: The authors declare no conflict of interest. The founding sponsors had no role in the design of the study; in the collection, analyses, or interpretation of data; in the writing of the manuscript, and in the decision to publish the results.

\section{References}

1. Kunamneni, A.; Ballesteros, A.; Plou, F.J.; Alcalde, M. Fungal laccase-A versatile enzyme for biotechnological applications. In Communicating Current Research and Educational Topics and Trends in Applied Microbiology; Mendez-Vilas, A., Ed.; Formex: Badajoz, Spain, 2007; Volume 1, pp. $233-245$. ISBN 978-84-611-9422-3.

2. Thurston, C.F. The structure and function of fungal laccases. Microbiology 1994, 140, 19-26. [CrossRef]

3. Wesenberg, D.; Kyriakides, I.; Agathos, S.N. White-rot fungi and their enzymes for the treatment of industrial dye effluents. Biotechnol. Adv. 2003, 22, 161-187. [CrossRef] [PubMed]

4. Misson, M.; Zhang, H.; Jin, B. Nanobiocatalyst advancements and bioprocessing applications. J. R. Soc. Interface 2015, 12, 20140891. [CrossRef] [PubMed]

5. Illanes, R. Enzyme Biocatalysis : Principles and Applications; Springer: Berlin, Germany, 2008.

6. Hernandez, R.; Fernandez-Lafuente, J.M. Control of protein immobilization: Coupling immobilization and site-directed mutagenesis to improve biocatalyst or biosensor performance. Enzyme Microb. Technol. 2011, 48, 107-122. [CrossRef] [PubMed]

7. Rodrigues, R.C.; Ortiz, C.; Berenguer-Murcia, A.; Torres, R.; Fernández-Lafuente, R. Modifying enzyme activity and selectivity by immobilization. Chem. Soc. Rev. 2013, 42, 6290-6307. [CrossRef] [PubMed]

8. Sheldon, R.A. Enzyme Immobilization: The Quest for Optimum Performance. Adv. Synth. Catal. 2007, 349, 1289-1307. [CrossRef] 
9. Duran, N.; Rosa, M.A.; D’Annibale, A.; Gianfreda, L. Applications of laccases and tyrosinases(phenoloxidases) immobilized on different supports: A review. Enzyme Microb. Technol. 2002, 31, 907-931. [CrossRef]

10. Cui, J.; Jia, S.; Liang, L.; Zhao, Y.; Feng, Y. Mesoporous CLEAs-silica composite microparticles with high activity and enhanced stability. Sci. Rep. 2015, 5, 14203. [CrossRef] [PubMed]

11. Matijosyte, I.; Arends, I.W.C.E.; Vries, S.; Sheldon, R.A. Preparation and use of cross-linked enzyme aggregates (CLEAs) of laccases. J. Mol. Catal. B Enzyme 2010, 62, 142-148. [CrossRef]

12. Qu, X.; Alvarez, P.J.J.; Li, Q. Applications of nanotechnology in water and wastewater treatment. Water Res. 2013, 47, 3931-3946. [CrossRef] [PubMed]

13. Ahn, M.-Y.; Zimmerman, A.R.; Martinez, C.E.; Archibald, D.D.; Bollag, J.-M.; Dec, J. Characteristics of Trametes villosa laccase adsorbed on aluminium hydroxide. Enzyme Microb. Technol. 2007, 41, 141-148. [CrossRef]

14. Qiu, H.; Xu, C.; Huang, X.; Ding, Y.; Qu, Y.; Gao, P. Adsorption of laccase on the surface of nanoporous gold and the electron transfer between them. J. Phys. Chem. C 2008, 112, 14781-14785. [CrossRef]

15. Fernandez-Fernandez, M.; Sanroman, M.A.; Moldes, D. Recent developments and applications of immobilized laccase. Biotechnol. Adv. 2013, 31, 1808-1825. [CrossRef] [PubMed]

16. Arroyo, M. Immobilized enzymes: Theory, methods of study and applications. ARS Pharm. 1998, 39, $23-39$.

17. Brady, D.; Jordaan, J. Advances in enzyme immobilisation. Biotechnol. Lett. 2009, 31, 1639-1650. [CrossRef] [PubMed]

18. García-Galán, C.; Berenguer-Murcia, A.; Fernandez-Lafuente, R.; Rodrigues, R.C. Potential of Different Enzyme Immobilization Strategies to Improve Enzyme Performance. Adv. Synth. Catal. 2011, 353, 2885-2904. [CrossRef]

19. Mazur, M.; Krysiński, P.; Michota-Kamińska, A.; Bukowska, J.; Rogalski, J.; Blanchard, G.J. Immobilization of laccase on gold, silver and indium tin oxide by zirconium-phosphonate-carboxylate (ZPC) coordination chemistry. Bioelectrochemistry 2007, 71, 15-22. [CrossRef] [PubMed]

20. Kalkan, N.; Aksoy, S.; Aksoy, E.; Hasirci, N. Preparation of chitosan-coated magnetite nanoparticles and application for immobilization of laccase. J. Appl. Polym. Sci. 2011, 123, 707-716. [CrossRef]

21. Feng, W.; Ji, P. Enzymes immobilized on carbon nanotubes. Biotechnol. Adv. 2011, 29, 889-895. [CrossRef] [PubMed]

22. DiCosimo, R.; McAuliffe, J.; Polouse, A.J.; Bohlmann, G. Industrial use of immobilized enzymes. Chem. Soc. Rev. 2013, 42, 6437-6474. [CrossRef] [PubMed]

23. Zimmermann, Y.S.; Shahgaldian, P.; Corvini, P.F.X.; Hommes, G. Sorption-assisted surface conjugation: A way to stabilize laccase enzyme. Appl. Microbiol. Biotechnol. 2011, 92, 169-178. [CrossRef] [PubMed]

24. Nobs, L.; Buchegger, F.; Gurny, R.; Allemann, E. Surface modification of poly(lactic acid) nanoparticles by covalent attachment of thiol groups by means of three methods. Int. J. Pharm. 2003, 29, 327-337. [CrossRef]

25. Barbosa, O.; Ortiz, C.; Berenguer-Murcia, A. Glutaraldehyde in bio-catalysts design: A useful crosslinker and a versatile tool in enzyme immobilization. RSC Adv. 2014, 4, 1583-1600. [CrossRef]

26. Zucca, P.; Sanjust, E. Inorganic materials as supports for covalent enzyme immobilization: Methods and mechanisms. Molecules 2014, 19, 14139-14194. [CrossRef] [PubMed]

27. Baumann, H.; Tillman, A.M. The Hitch Hilker's Guide to LCA: An Orientation in Life Cycle Assessment Methodology and Application; Studentlitteratur: Lund, Sweden, 2004; ISBN 9144023642.

28. Environmental Management_Life Cycle Assessment_Principles and Framework; ISO 14040:2006; International Organization for Standardization: Geneva, Switzerland, 2006.

29. Feijoo, S.; Gonzalez-García, S.; Moldes-Diz, Y.; Vazquez-Vazquez, C.; Feijoo, G.; Moreira, M.T. Comparative life cycle assessment of different synthesis routes of magnetic nanoparticles. J. Clean. Prod. 2017, 43, 528-538. [CrossRef]

30. Dones, R.; Bauer, C.; Bolliger, R.; Burger, B.; Faist, E.M.; Frischknecht, R.; Heck, T.; Jungbluth, N.; Röder, A.; Tuchschmid, M. Life Cycle Inventories of Energy Systems: Results for Current Systems in Switzerland and Other UCTE Countries; Ecoinvent Report No. 5; Swiss Centre for Life Cycle Inventories: Düberdorf, Switzerland, 2007; Available online: https:/ / www.researchgate.net/profile/Deborah_Andrews2/publication/271710820_ The_life_cycle_assessment_of_a_UK_data_centre/links/5620b9ec08aed8dd194054ea.pdf (accessed on 7 June 2016). 
31. Althaus, H.J.; Chudacoff, M.; Hischier, R.; Jungbluth, N.; Osses, M.; Primas, A. Life Cycle Inventories of Chemicals; Ecoinvent Report No.8 v2.0 EMPA; Swiss Centre for Life Cycle Inventories: Düberdorf, Switzerland, 2007.

32. Doka, G. Life Cycle Inventories of Waste Treatment Services; Ecoinvent Report No. 13; Swiss Centre for Life Cycle Inventories: Dübendorf, Switzerland, 2003.

33. Red Eléctrica de España. Avance del Informe del Sistema Eléctrico Español 2014. Available online: http: / / www.ree.es/sites / default/ files/downloadable/avance_informe_sistema_electrico_2014.pdf (accessed on 10 June 2016).

34. Goedkoop, M.J.; Heijungs, R.; Huijbregts, M.; Schryver, A.D.; Strujis, J.; Zelm, R. A Life Cycle Impact Assessment Method Which Comprises Harmonised Category Indicators at the Midpoint and the Endpoint Level. Available online: http://www.leidenuniv.nl/cml/ssp/publications/recipe_characterisation.pdf (accessed on 7 June 2016).

35. PRé Consultants. 2017. Available online: http:/ / www.pre.nl (accessed on 1 July 2017).

36. Sheldon, R.A. Cross-linked enzyme aggregates (CLEAs): Stable and recyclable biocatalysts. Biochem. Soc. Trans. 2007, 35, 1583-1587. [CrossRef] [PubMed]

37. Ovsejevi, K.; Manta, C.; Batista-Viera, F. Reversible covalent immobilization of enzymes via disulfide bonds. Methods Mol. Biol. 2013, 1051, 89-116. [CrossRef] [PubMed]

38. Guisán, J.M. Immobilization of Enzymes and Cells, 2nd ed.; Humana Press Inc.: Clifton, NJ, USA, 2006; ISBN 978-1-58829-290-2.

39. Flickinger, M.; Drew, S. Encyclopedia of Bioprocess Technology: Fermentation, Biocatalysis and Bioseparation Fermentation, Biocatalysis and Bioseparation; Wiley: New York, NY, USA, 1999; ISBN 0-471-13822-3.

40. Majumder, A.B.; Mondal, K.; Singh, T.P.; Gupta, M.N. Designing cross-linked lipase aggregates for optimum performance as biocatalysts. Biocatal. Biotransform. 2008, 26, 235-242. [CrossRef]

41. Kumar, S.; Jana, A.K.; Maiti, M.; Dhamija, I. Carbodiimide-mediated immobilization of serratiopeptidase on amino-, carboxyl-functionalized magnetic nanoparticles and characterization for target delivery. J. Nanopart. Res. 2014, 16, 2233. [CrossRef]

42. Arca-Ramos, A.; Ammann, E.M.; Gasser, C.A.; Nastold, P.; Eibes, G.; Feijoo, G.; Lema, J.M.; Moreira, M.T.; Corvini, P.F.X. Assessing the use of nanoimmobilized laccases to remove micropollutants from wastewater. Environ. Sci. Pollut. Res. 2016, 23, 3217-3228. [CrossRef] [PubMed]

43. Corgié, S.; Kahawong, P.; Duan, X.; Bowser, D.; Edward, J.B.; Walker, L.P.; Giannelis, E.P. Self-assembled complexes of horseradish peroxidase with magnetic nanoparticles showing enhanced peroxidase activity. Adv. Funct. Mater. 2012, 22, 1940-1951. [CrossRef]

44. Claus, H.; Faber, G.; König, H. Redox-mediated decolorization of synthetic dyes by fungal laccases. Appl. Microbiol. Biotechnol. 2002, 59, 672-678. [CrossRef] [PubMed]

45. Wang, F.; Hu, Y.; Guo, C.; Huang, W.; Liu, C.-Z. Enhanced phenol degradation in cooking wastewater by immobilized laccase on magnetic mesoporous silica nanoparticles in a magnetically stabilized fluidized bed. Bioresour. Technol. 2012, 110, 120-124. [CrossRef] [PubMed]

46. Kurniawati, S.; Nicell, J.A. A Comprehensive Kinetic Model of Laccase-Catalyzed Oxidation of Aqueous Phenol. Biotechnol. Prog. 2009, 25, 763-773. [CrossRef] [PubMed]

47. Bayramoglu, G.; Arica, M.Y. Enzymatic removal of phenol and p-chlorophenol in enzyme reactor: Horseradish peroxidase immobilized on magnetic beads. Hazard. Mater. 2008, 156, 148-155. [CrossRef] [PubMed]

48. Grieger, K.D.; Laurent, A.; Miseljic, M.; Christensen, F.; Baun, A.; Olsen, S.I. Analysis of current research addressing complementary use of life-cycle assessment and risk assessment for engineered nanomaterials: Have lessons been learned from previous experience with chemicals? J. Nanopart. Res. 2012, $14,958$. [CrossRef]

(C) 2017 by the authors. Licensee MDPI, Basel, Switzerland. This article is an open access article distributed under the terms and conditions of the Creative Commons Attribution (CC BY) license (http://creativecommons.org/licenses/by/4.0/). 